\title{
Perceptions of Process Qualtty in BUILDING PROJects
}

\author{
By David Arditi, ${ }^{1}$ Member, ASCE, and H. Murat Gunaydin, ${ }^{2}$ Student Member, ASCE
}

\begin{abstract}
A Delphi process and a questionnaire survey are conducted to investigate the differences in the perceptions of entry-level professionals and long-time practitioners with regard to process quality in building projects. The factors that affect process quality in the three phases (design, construction, and operation) of a building project's life cycle are identified and ranked by the respondents' perceived degree of importance. The findings indicate that the perceptions of entry-level professionals and long-time practitioners are in agreement for most (74\%) of the factors. Given the differences in the respondents' background, expectations, and experience, differences in perceptions are to be expected in the remaining $26 \%$ of the factors. Analyzing these differences helps in revising and improving existing training courses and academic programs. It is recommended that college programs include courses that treat the administrative aspects involved in the building project in great detail and that continuing education programs cover quality training and life cycle cost analysis.
\end{abstract}

\section{INTRODUCTION}

Product and process quality in the building construction industry is moving toward higher levels. Traditional quality assurance and quality control procedures are being implemented in the industry. Emerging process-centered quality improvement techniques (e.g., total quality management, reengineering, etc.) that became popular in the manufacturing industry are now also being used successfully in the building construction industry. More emphasis is given to process quality to increase product quality and to satisfy all stakeholders in the industry.

One should differentiate between "product quality" (i.e., the quality of elements directly related to the physical product itself) and "process quality" (i.e., the quality of the process that causes the product to be either acceptable or not) (Nagasaku and Oda 1965). For example, product quality in the construction industry refers to achieving quality in the materials, equipment, and technology that go into the building of a structure. On the other hand, process quality refers to achieving quality in the way the project is organized and managed in the three phases of design, construction, and operation.

${ }^{1}$ Prof., Dept. of Civ. and Arch. Engrg., Illinois Inst. of Technol., Chicago, IL 60616. E-mail: arditi@charlie.cns.iit.edu

${ }^{2}$ Grad. Student, Dept. of Civ. and Arch. Engrg., Illinois Inst. of Technol., Chicago, IL, and Res. Asst., Izmir Inst. of Tech., Izmir 35230, Turkey. E-mail: gunahus@charlie.cns.iit.edu

Note. Discussion open until September 1, 1999. To extend the closing date one month, a written request must be filed with the ASCE Manager of Journals. The manuscript for this paper was submitted for review and possible publication on November 4, 1997. This paper is part of the Journal of Management in Engineering, Vol. 15, No. 2, March/April, 1999. CASCE, ISSN 0742-597X/99/0002-0043-0053/ $\$ 8.00+\$ .50$ per page. Paper No. 16903 .
The building construction process employs professionals from several disciplines (e.g., civil, architectural, mechanical, electrical, etc.), but civil engineers and architects generally dominate the process. Their attitude is vital for quality improvement. As the demand for construction professionals increases (Russell 1991), their education and training needs in the basic quality concepts become more apparent. This paper aims to highlight the differences in how entry-level professionals and longtime professionals perceive process quality in the building construction industry. The research takes a holistic approach to the study of the building process, investigating quality issues in the design, construction, and operation phases of a building project. Thus, it is expected that process-oriented quality improvement efforts can be of benefit in all the phases of the construction activity. Analyzing the differences in new graduates' and experienced professionals' perceptions of quality-related issues may help to revise and improve existing training courses and academic programs and to develop new programs that emphasize process quality in educating civil engineers, architects, and technologists. It may also help with developing continuing education programs and refresher courses that highlight process quality for the consumption of experienced professionals.

\section{DEFINITION OF QUALITY}

According to Juran (1988), quality can be defined in terms of (1) conformance to the agreed requirements of the customer and (2) a product or service free of deficiencies. The American Society for Quality (www.asq.org) and Crosby (1992) support this definition. 
In the building construction industry, quality can be defined as meeting the requirements of the designer, constructor, and regulatory agencies as well as the owner (Arditi and Gunaydin 1997). In terms of function, a high quality building project can be described by such terms as ease in understanding drawings, level of agreement in drawings and specifications, economics of construction, ease of operation, ease of maintenance, and energy efficiency.

\section{Quality Assurance}

According to the Manual of Professional Practice for Quality in the Constructed Project (Ferguson and Clayton 1988), "Quality Assurance (QA) is a program covering activities necessary to provide quality in the work to meet the project requirements. QA involves establishing project related policies, procedures, standards, training, guidelines, and system necessary to produce quality. The design professional and constructor are responsible for developing an appropriate program for each project. Quality assurance provides protection against quality problems through early warnings of trouble ahead. Such early warnings play an important role in the prevention of both internal and external problems." The assurance is provided from objective evidence (Juran 1988), but the type of evidence differs widely according to the persons requiring the assurance and the nature of the product.

\section{Quality Control}

Quality control is the specific implementation of the quality assurance program and related activities. Effective quality control reduces the possibility of changes, mistakes and omissions, which in turn results in fewer conflicts and disputes. The term "quality control" has had a short history. Early in the twentieth century, it began to be used as a synonym for defect prevention. However, during the 1940s and 1950s there was a wave of enthusiasm for the use of statistical methods in quality control (Juran 1988). The proponents of this movement coined the phrase "statistical quality control" and publicized it so widely that many managers gained the impression that quality control consisted of the use of statistical methods in industry. As a consequence, the statistical quality control movement weakened the use of quality control as an accepted term for the regulatory process (O'Brien 1989).

The Japanese Industrial Standards Z8101-1981 define quality control as a system for the economical production of goods and services that meet the demands of the consumers (Iami 1986). The standard for all actions and activities in quality control is that they must contribute to the satisfaction of the customer. On the other hand, according to Crosby (1967), quality control concepts, techniques, and practices were developed around assumptions of the inevitability of error and made no room for a defect-free situation. When one occurred, the assumption was that something had been missed and that it was due only to the inadequacy of the appraisal effort. Quality was only applied to the manufacturing activity.
In the 1960s and 1970s, various terms such as "total quality control," "zero defects," and "product assurance" emerged as alternatives to the use of quality control as an all-inclusive term for the regulatory process (Juran 1988). During the mid-1980s there emerged a revival of keen interest in statistical methodology, this time under the name "statistical process control" (O'Brien 1989).

The terms quality assurance and quality control are frequently used interchangeably. Because quality control is a part of quality assurance (Ferguson and Clayton 1988), maintaining a clear distinction between them is difficult but important. Quality assurance is a planned and systematic action necessary to provide adequate confidence that a structure, system, or component will perform satisfactorily and conform with project requirements. On the other hand, quality control is a set of specific procedures involved in the quality assurance process. These procedures include planning, coordinating, developing, checking, reviewing, and scheduling the work. The quality control function is closest to the product in that various techniques and activities are used to monitor the process and to pursue the elimination of sources that lead to unsatisfactory quality performance. Most design-related quality assurance and quality control activities are covered by a design organization's standard office procedures. Developing and implementing the activities within the quality assurance program in the construction phase are the responsibility of the construction company; this is monitored either by the designer or the construction management firm depending on the project delivery system in use.

\section{METHODOLOGY}

A thorough literature review was conducted to identify the factors that affect quality as recognized by researchers and practitioners in this field. The life-cycle phases of building projects were defined as design, construction, and operation; and the factors that affect quality in each phase were identified. In the first part of the study, the perceptions of entry-level professionals were determined by means of a Delphi process. In the second part, four types of questionnaires were designed using the same format used in the Delphi questionnaires, and they were administered to four groups of respondents, namely, designers, contractors, property managers, and construction managers. The findings of the second part of the study are reported elsewhere (Arditi and Gunaydin 1998).

The Delphi process was designed to investigate the opinions and expectations of entry-level professionals with limited or no practical work experience. The Delphi technique is a method for the systematic solicitation and collation of judgments on a particular topic through a set of carefully designed sequential questionnaires interspersed with summarized information and feedback of opinions derived from earlier responses. Each subsequent questionnaire is built upon responses to the preceding questionnaire. The process stops when consensus has been approached among participants or when suffi- 
cient information exchange has been obtained (Delbecq and Gustafson 1975).

The Delphi process was conducted in three rounds with a week between rounds with a graduate class in the Construction Engineering and Management Program at the Illinois Institute of Technology. The main criteria used in the selection of the participants were work experience, availability, and accessibility. Fourteen participants took part in the study and no changes of participants were made during the iterative process. The group consisted of four architects and 10 civil engineers. Seventy percent of the participants had less than 1 year of professional experience in design and/or site-related activity. The questionnaire used in the process is presented in Appendix I.

In the second part of the study, three different questionnaires (A, B, and $\mathrm{C}$ ) were prepared to investigate long-time practitioners' perceptions of process quality in the design, construction, and operation phases of a building project, respectively. Questionnaire A was administered to the top 100 design firms ("The top" 1994d), Questionnaire B to the top 100 construction companies ("The top" 1994c), and Questionnaire C to the top 100 property management firms ("The top" 1994b). Also, a combination of the Questionnaires A, B, and C incorporating questions pertaining to the design, construction, and operation phases was administered to the top 100 construction management firms ("The top" 1994a). The rates of response in these four surveys were 41, 35, 30, and $31 \%$ for designers, contractors, property managers, and construction managers, respectively (overall rate of response was $34.50 \%$ ).

\section{FINDINGS AND ANALYSIS}

The objective of this research was to explore and identify the differences between the perceptions of entry- level professionals and long-time practitioners with regard to process quality in the building construction project. The differences between the means of the responses received from entry-level professionals and long-term practitioners were tested by conducting Spearman's rank correlation and Duncan's multiple range tests separately for the data that pertains to the design, construction, and operation phases. The means and standard deviations of the answers to the questions posed in the Delphi process conducted with entry-level professionals and of the mail survey administered to long-time practitioners are presented in Tables $1-3$. The results of Duncan's multiple range tests that established whether the differences in the means are statistically significant at $1 \%$ are also presented in these tables. The modified version of Duncan's multiple range test for unequal sample sizes is used in this comparison (Milton and Arnold 1990). It should be noted here that the findings and recommendations are based on a survey of 137 long-time practitioners who represent the largest firms in their respective fields of activity and 14 entry-level professionals.

\section{Design Phase}

In the design phase, the Spearman rank correlation between entry-level professionals' and long-time practitioners' perceptions is 0.77 (significant at $0.5 \%$ ). Even though the correlation is quite high, it appears that there also are some disagreements (Table 1). The educational background of designers, designers' training, communication with the owner, and the design budget allocated by the owner are the factors that are found to be more important by entry-level professionals than by long-time construction managers and designers. Duncan's multiple range tests indicate that differences are significant at $1 \%$ (Table 1).

TABLE 1. Ranking of Factors that Affect Process Quality in Design Phase

\begin{tabular}{|c|c|c|c|c|c|c|c|}
\hline \multirow[b]{2}{*}{$\begin{array}{c}\text { Factors } \\
\text { (1) }\end{array}$} & \multicolumn{3}{|c|}{ Entry-Level Professionals } & \multicolumn{3}{|c|}{ Long-Time Practitioners } & \multirow[b]{2}{*}{$\begin{array}{l}\text { Difference of means statistically } \\
\text { significant at } 1 \% \\
(8)\end{array}$} \\
\hline & $\begin{array}{c}\text { Rank } \\
\text { (2) }\end{array}$ & $\begin{array}{c}\text { Mean }^{a} \\
\text { (3) }\end{array}$ & $\begin{array}{l}\text { Standard } \\
\text { deviation } \\
\text { (4) }\end{array}$ & $\begin{array}{c}\text { Rank } \\
\text { (5) }\end{array}$ & $\begin{array}{c}\text { Mean }^{\mathrm{b}} \\
\text { (6) }\end{array}$ & $\begin{array}{l}\text { Standard } \\
\text { deviation } \\
\text { (7) }\end{array}$ & \\
\hline Project specifications & 1 & 4.92 & 0.56 & 2 & 8.90 & 1.33 & No \\
\hline Communication with owner & 2 & 4.91 & 0.59 & 7 & 8.50 & 1.74 & Yes \\
\hline Design budget & 3 & 4.79 & 0.41 & 9 & 8.25 & 1.67 & Yes \\
\hline Management leadership & 4 & 4.78 & 0.41 & 4 & 8.80 & 1.34 & No \\
\hline Constructability & 5 & 4.71 & 0.45 & 8 & 8.37 & 1.62 & No \\
\hline Cooperation of parties & 6 & 4.70 & 0.26 & 1 & 9.09 & 1.39 & No \\
\hline Selection of design firm & 7 & 4.67 & 0.49 & 5 & 8.55 & 1.29 & No \\
\hline Teamwork in design firm & 8 & 4.64 & 0.48 & 3 & 8.88 & 1.31 & No \\
\hline Management commitment & 9 & 4.43 & 0.73 & 6 & 8.54 & 1.95 & No \\
\hline Feedback system & 10 & 4.36 & 0.72 & 10 & 7.60 & 1.79 & No \\
\hline Designer's training & 11 & 4.29 & 0.45 & 13 & 7.10 & 1.72 & Yes \\
\hline Designer's education & 12 & 4.14 & 0.83 & 16 & 6.13 & 1.66 & Yes \\
\hline Office practices & 13 & 4.08 & 0.76 & 14 & 6.93 & 1.98 & No \\
\hline Codes and standards & 14 & 3.57 & 0.90 & 12 & 7.34 & 1.94 & No \\
\hline Personalities & 15 & 3.43 & 0.98 & 15 & 6.80 & 1.90 & No \\
\hline Drafting practices & 16 & 3.36 & 0.97 & 11 & 7.39 & 1.58 & No \\
\hline Statistical methods & 17 & 3.21 & 0.94 & 17 & 5.50 & 1.80 & No \\
\hline
\end{tabular}

Note: Sample sizes - entry-level professionals: 14 graduate students; long-time practitioners: 41 designers and 31 construction managers.

${ }^{a}$ Scoring system scale of 1-5: 1 not important, 5 very important.

${ }^{\mathrm{b}}$ Scoring system scale of 1-10: 1 not important, 10 very important. 
TABLE 2. Ranking of Factors that Affect Process Quality in Construction Phase

\begin{tabular}{|c|c|c|c|c|c|c|c|}
\hline \multirow[b]{2}{*}{$\begin{array}{c}\text { Factors } \\
\text { (1) }\end{array}$} & \multicolumn{3}{|c|}{ Entry-Level Professionals } & \multicolumn{3}{|c|}{ Long-Time Practitioners } & \multirow[b]{2}{*}{$\begin{array}{l}\text { Difference of means statistically } \\
\text { significant at } 1 \% \\
(8)\end{array}$} \\
\hline & $\begin{array}{c}\text { Rank } \\
\text { (2) }\end{array}$ & $\begin{array}{l}\text { Mean }^{a} \\
\text { (3) }\end{array}$ & $\begin{array}{l}\text { Standard } \\
\text { deviation } \\
\quad(4)\end{array}$ & $\begin{array}{c}\text { Rank } \\
(5)\end{array}$ & $\begin{array}{c}\text { Mean }^{\mathrm{b}} \\
(6)\end{array}$ & $\begin{array}{l}\text { Standard } \\
\text { deviation } \\
\quad(7)\end{array}$ & \\
\hline Selection of contractor & 1 & 4.93 & 0.26 & 5 & 8.94 & 1.33 & Yes \\
\hline Management commitment & 2 & 4.86 & 0.35 & 4 & 9.01 & 1.32 & No \\
\hline Cooperation of parties & 3 & 4.86 & 0.35 & 3 & 9.03 & 1.07 & No \\
\hline Management leadership & 4 & 4.79 & 0.41 & 1 & 9.20 & 1.12 & No \\
\hline Teamwork in construction firm & 5 & 4.79 & 0.41 & 6 & 8.62 & 1.02 & Yes \\
\hline Management techniques & 6 & 4.79 & 0.41 & 10 & 8.08 & 1.48 & Yes \\
\hline Construction budget & 7 & 4.79 & 0.56 & 9 & 8.10 & 1.90 & Yes \\
\hline Shop drawings & 8 & 4.71 & 0.45 & 11 & 8.08 & 1.48 & Yes \\
\hline Supervision by contractor & 9 & 4.71 & 0.45 & 2 & 9.08 & 1.04 & No \\
\hline Feedback system & 10 & 4.50 & 0.73 & 14 & 7.41 & 2.07 & Yes \\
\hline Drawings and specs & 11 & 4.46 & 0.49 & 7 & 8.52 & 1.75 & No \\
\hline Employee training & 12 & 4.28 & 0.45 & 8 & 8.39 & 1.25 & No \\
\hline Contract forms & 13 & 4.07 & 0.96 & 17 & 6.45 & 2.50 & No \\
\hline Technologies used & 14 & 4.07 & 0.59 & 13 & 7.49 & 1.55 & No \\
\hline Supervision by owner & 15 & 3.79 & 0.77 & 15 & 7.20 & 2.03 & No \\
\hline Supplier involvement & 16 & 3.79 & 1.15 & 16 & 6.67 & 1.84 & No \\
\hline Personalities & 17 & 3.64 & 0.97 & 12 & 7.53 & 1.92 & No \\
\hline Statistical methods & 18 & 3.36 & 0.61 & 18 & 5.51 & 2.47 & No \\
\hline
\end{tabular}

Note: Sample sizes - entry-level professionals: 14 graduate students; long-time practitioners: 31 contractors and 35 construction managers.

${ }^{\text {a }}$ Scoring system scale of $1-5: 1$ not important, 5 very important.

${ }^{\mathrm{b}}$ Scoring system scale of $1-10: 1$ not important, 10 very important.

TABLE 3. Ranking of Factors that Affect Process Quality in Operation Phase

\begin{tabular}{|c|c|c|c|c|c|c|c|}
\hline \multirow[b]{2}{*}{$\begin{array}{c}\text { Factors } \\
\text { (1) }\end{array}$} & \multicolumn{3}{|c|}{ Entry-Level Professionals } & \multicolumn{3}{|c|}{ Long-Time Practitioners } & \multirow[b]{2}{*}{$\begin{array}{l}\text { Difference of means statistically } \\
\text { significant at } 1 \% \\
(8)\end{array}$} \\
\hline & $\begin{array}{c}\text { Rank } \\
\text { (2) }\end{array}$ & $\begin{array}{c}\text { Mean }^{a} \\
\text { (3) }\end{array}$ & $\begin{array}{l}\text { Standard } \\
\text { deviation } \\
\text { (4) }\end{array}$ & $\begin{array}{c}\text { Rank } \\
\text { (5) }\end{array}$ & $\begin{array}{c}\text { Mean }^{\mathrm{b}} \\
(6)\end{array}$ & $\begin{array}{l}\text { Standard } \\
\text { deviation } \\
\quad(7)\end{array}$ & \\
\hline Operation budget & 1 & 4.86 & 0.35 & 5 & 8.31 & 1.51 & Yes \\
\hline Personnel training & 2 & 4.50 & 0.79 & 1 & 9.16 & 0.98 & No \\
\hline Management leadership & 3 & 4.50 & 0.79 & 2 & 8.92 & 1.54 & No \\
\hline Management commitment & 4 & 4.43 & 0.73 & 3 & 8.70 & 1.55 & No \\
\hline Operation within design limits & 5 & 4.29 & 0.69 & 6 & 8.19 & 1.67 & No \\
\hline Maintenance manual & 6 & 4.14 & 0.64 & 4 & 8.37 & 1.80 & No \\
\hline Personalities & 7 & 3.79 & 1.01 & 8 & 6.84 & 2.02 & No \\
\hline Automation of building services & 8 & 3.57 & 1.05 & 7 & 7.19 & 1.79 & No \\
\hline
\end{tabular}

Note: Sample sizes — entry-level professionals: 14 graduate students; long-time practitioners: 30 property managers and 31 construction managers.

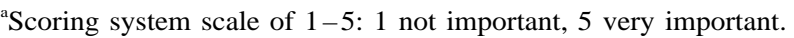

${ }^{\mathrm{b}}$ Scoring system scale of $1-10$ : 1 not important, 10 very important.

The finding that the educational background of designers is found to be relatively more important by entrylevel professionals (ranked 12th) than by long-time practitioners (ranked 16th) can be explained by the higher expectations of the new graduates who have recently invested considerable time and money into their education. Designers' training, on the other hand, covers in-house training courses and continuing education programs designed to bring them up to date in new developments in practice-oriented quality issues. The fact that entry-level professionals ranked designers' training as more important (11th), compared with long-time practitioners (13th), is indicative of the higher value that entry-level professionals attach to continuing education and training in general.

Juran, Deming, and Crosby emphasized education and training but with different focuses. Juran (1993) covered quality management practices and problem-solving tech- niques. He provided a systems approach to quality control and improvements for all parts of the organization. Deming's focus was on statistical techniques as discussed by Neave (1990). Crosby's (1992) training was targeted toward developing a new quality culture and implementing the quality improvement process. It is noted, however, that both of these education-related factors, the educational background of designers and designers' training, are ranked quite low (12th and 11th, respectively) in importance by entry-level professionals, indicating that factors like project specifications, communication with the owner, design budget, management leadership, and constructability, to name but the first five factors, are of greater priority in achieving high process quality than education and training.

Communication with the owner in the design phase has to be handled carefully. The owner defines the project requirements and transmits those requirements 
effectively to the other parties involved in this process. This phase also involves the other parties briefing the owner and extracting from the owner relevant information that is necessary for high quality design and construction. Requirements may change throughout the process. Improved and systematic communications may save money and time and may eliminate aggravation for all parties. According to Covey (1990) win-win situations depend on well-defined requirements through effective communication. It is interesting that entry-level professionals who have probably never dealt with an owner consider this factor to be of more importance (ranked second) than long-time practitioners (ranked seventh). It may be that this is a misconception on the part of inexperienced professionals who later in their professional lives discover that dealing with owners is after all not always so difficult and strained.

The design budget is vital to the quality of design. It is ranked third by entry-level professionals and ninth by long-time practitioners. It can be speculated that designers and construction managers who have had some work experience also know that the designer will not take a job if the budget is not adequate unless in exceptional cases where the scope of work is adjusted. On the other hand, the novice professional may have the misconception that a designer may get stuck with a design job that is not adequately funded. The source for this misconception may lie in the traditional way (negotiation) a design job is awarded as opposed to the traditional way (bidding) a construction job is awarded.

Duncan's multiple range tests indicate that entry-level professionals and long-time practitioners agree on the relative importance of the remaining factors. The interpretation of the ranking of the remaining factors is treated in detail by Arditi and Gunaydin (1997).

\section{Construction Phase}

In the construction phase, a Spearman rank correlation coefficient of 0.79 is found between rankings of entrylevel professionals and long-time practitioners, namely, construction managers and contractors (Table 2). This relationship is statistically significant at $0.5 \%$. Management leadership, management commitment to continuous quality improvement, and cooperation of the parties involved in construction are the factors that all parties, including entry-level professionals and long-time practitioners ranked within the top five. There are also some disagreements. These disagreements may be the result of the different priorities attached to each factor by the different parties.

Selection of the contractor, teamwork in the construction company, management techniques used, the construction budget, shop drawings, and the feedback system are the factors that are found to be significantly more important by entry-level professionals than by long-time practitioners. Duncan's multiple range tests indicate that the differences are statistically significant at $1 \%$.

When the selection of the contractor is conducted by bidding, the lowest qualified bidder is normally awarded the construction job. Bidding entails a great deal of time and effort on the part of contractors and involves decisions that require contractors to make a fair number of quality-related assumptions. Whereas long-time practitioners may see this activity as routine, entry-level professionals may consider it as a "make or break" type of activity that has an overwhelming impact on the construction company's survival. This state of mind may explain why entry-level professionals ranked this factor first whereas long-time practitioners ranked it fifth.

Teamwork is an essential part of the job if conflicts and disputes are to be avoided. Quality teams provide companies with the structured environment necessary for successfully implementing and continuously applying a quality improvement process. Quality training can be conducted and the continuous improvement process executed through a well-planned team structure. The ultimate goal of the team approach is to get everyone involved with the process of improving quality. The organization and structure of teams are subject to change from firm to firm, even from job to job. According to Deming (1986) teams may improve the quality of the process if they are allowed to express their opinions. Teams may improve construction techniques and productivity and therefore reduce the amount of rework and decrease the costs. An inadequate level of coordination, on the other hand, may lead to major conflicts such as overlapping activities, material shortages, and inefficient resource allocation. It is interesting that, in this study, entry-level professionals are found to attach greater importance to teamwork at the construction company level (ranked fifth) than long-time practitioners (ranked sixth).

In the case of management techniques, it is interesting that long-time contractors and construction managers do not consider this factor to have as much impact as entrylevel professionals believe it has on the level of process quality achieved in a building construction project. The finding may mean that many construction managers and contractors are not fully aware of the state-of-the-art applications in modern management techniques and of their implications even though they have been active in this field for a long time. This argument is easier to justify for contractors than for construction managers because one of the reasons for the emergence of the construction management profession is the inadequacy of contractors in this activity. The finding may also mean that entry-level professionals have been exposed to the latest management techniques in their most recently completed education programs and therefore appreciate the importance more than long-time practitioners who were never exposed to such techniques or who were exposed to them many years ago.

The construction budget is ranked seventh by entrylevel professionals and ninth by long-time practitioners. The budget allocated by the owner for construction activities greatly affects the schedule of work and the quality of performance. The construction budget has to be considered early in the design phase. Architects and engineers can design both spartan or luxury buildings in terms of technologies used and facilities provided that perform the same basic functions required by the owner. 
Therefore if the financial resources and limits are clear at the beginning, the requirements of the owner can be satisfied within these boundaries. The budget allocated for construction has to be supported by the specifications of the project, otherwise project integrity and consistency will be in danger. The difference in the opinions of entry-level professionals and long-time practitioners may be attributed to the experience levels of the parties. Entry-level professionals may have an exaggerated view of the gravity and frequency of potential situations where it is impossible to meet the owner's requirements within the given budget, whereas long-time practitioners know that such situations occur only rarely as long as the owner's requirements are clear and the contractor did not make a mistake in the bidding process.

Rejected shop drawings constitute a classic type of nonconformance (Stasiowski and Burstein 1994). Regardless of who is at fault, such rejections are very damaging to all parties. Reducing the frequency of such rejections will certainly improve the quality of the process. At the other extreme, designers are sometimes given a set of shop drawings to review but some nonconformances slip through the review process and create major and costly problems in the field. Shop drawings are at the front line of the transformation process. Therefore, details have to be carefully designed and engineered with conformance to overall limits and objectives of the project. Entry-level professionals ranked this factor eighth, whereas long-time practitionars ranked it 11th. This difference may be the result of the habit-induced attitude of long-time practitioners toward shop drawings. They may accept the rejections and faults resulting from shop drawings much more easily than entry-level professionals because they may feel that such problems are inevitable. One may also suggest that they get used to these kinds of faults. Here the training of long-time practitioners may change their perceptions that then may help with the improvement of the quality of the process.

Formal feedback systems collect data and information throughout the process and store it in a retrievable format for future uses. This may be effective for organizational documentation and learning. However, feedback can also be obtained from professionals. Teamwork environments and process-centered approaches may improve professionals' ability to exchange their experiences and ideas with each other (Hammer 1996; Drucker 1993). For the latter case not only data and information but also knowledge and wisdom can be shared. Lessons learned from constructed facilities can effectively be transferred to the construction organizations by both formal and informal feedback systems. Formal and informal feedback systems have to be promoted to a level where lessons learned can be utilized fully throughout the organization. The importance of the feedback systems is ranked 10th and 14th by entry-level practitioners and long-time professionals, respectively. This difference may be linked to entry-level professionals' beliefs in the effectiveness of feedback systems as a source from which they can extract experience-based information that they lack, whereas some long-time practitioners may think that they do not need any feedback system to tell them what they already know.

\section{Operation Phase}

In the operation phase, there is a relatively low rank correlation coefficient of 0.69 between the opinions of entry-level professionals and long-time practitioners. This relationship is statistically significant at $0.5 \%$. The budget allocated by the owner for operation and maintenance is found to be relatively more important by entry-level professionals (ranked first) than by long-time construction managers and property managers (ranked fifth). Duncan's multiple range tests indicate that the difference is statistically significant at $1 \%$. It is possible that inexperienced professionals' perceptions of the importance of the operation and maintenance budget is based on their too recent education that typically does not cover any information regarding the operation and maintenance of buildings. For example, designers traditionally operate with initial cost constraints rather than life cycle cost considerations, and contractors seldom contribute ideas that impact operation and maintenance decisions. It appears that entry-level professionals think that if the operation and maintenance budget is adequate, then it will be easy to impact the quality of the building services including operation, maintenance, and repairs. For long-time practitioners, however, factors such as the training of the personnel, management leadership and commitment to quality improvement, and the existence of a well-documented maintenance manual are of much greater importance than the budget.

\section{CONCLUSIONS}

The differences between the opinions of entry-level professionals and long-time practitioners are not statistically significant for $74 \%$ of the factors (32 out of a total of 43) that were investigated in the design, construction, and operation phases of a building project. Therefore, there seems to be agreement between entrylevel professionals and long-time practitioners concerning the importance of most of the factors in relation to process quality in building construction. For example, both entry-level professionals and long-time practitioners rank the use of statistical methods at the very bottom of the importance list. On the other hand, both entrylevel professionals and long-time practitioners rank as the top five most important factors project specifications and management leadership in the design phase, management leadership and commitment and cooperation of the parties involved in the construction phase, and personnel training and management leadership and commitment in the operation phase. It is very clear that management leadership in promoting process quality issues in all three phases of the building project is the top priority of entry-level professionals and long-time practitioners. In addition, project specifications must clearly state quality expectations; parties involved in the construction process must be totally committed to make quality a top priority; and the personnel in charge of 
building operation and maintenance must be trained to deliver high quality service.

Differences in the perceptions of experienced practitioners and novice professionals in relation to process quality in the building project are also to be expected given the differences in their background, expectations, and experience. The educational background of designers, designers' training, communication with the owner, and the design budget allocated by the owner are the factors that are found to be more important by entrylevel professionals than by long-time practitioners in the design phase. Selection of the contractor, teamwork in the construction company, management techniques used, the construction budget, shop drawings, and the feedback system are the factors that are found to be relatively more important by entry-level professionals than by long-time practitioners in the construction phase. Finally, the budget allocated by the owner for operation and maintenance is found to be relatively more important by entry-level professionals than by long-time construction managers and property managers who are active in the operation phase. These differences are statistically significant at $1 \%$. Recent graduates' high expectations of the educational system in whose services they recently invested a great deal of time and money, their desire to apply new management technologies within given budgets, and their relatively high energy are perhaps some of the major factors that explain the differences in the perceptions regarding issues of process quality.

It is interesting to note that the budget was found to be relatively more important by entry-level professionals than by long-time practitioners in all three phases of the life cycle of a building project. The danger that an in- adequate budget will affect negatively the quality of the process originates from the uncertainties involved in the selection of the designer, the contractor, and the property manager. It appears that entry-level professionals have misconceptions regarding the negotiation and bidding processes traditionally used to select the designer and the contractor, respectively. They are not quite sure whether life-cycle costs have been considered or neglected in the original feasibility study and whether this situation reflects on the quality of the activities undertaken in the operation phase.

Surveys of construction management programs indicate that all such programs include at least one course that treats the procedural aspects of the construction activity (Arditi 1984; Ledbetter 1985; Yates 1994). A cursory look into civil engineering and architecture curricula also suggests that such courses are typically part of current curricula. The extent to which quality issues are treated in these courses is of course not known. In the absence of such information, it is recommended that these courses include the procedural aspects involved in the building project in great detail. These topics could include negotiations for design services, bidding for construction work, project specifications, the role of management leadership in promoting quality issues and management commitment to continuously improving quality standards, and, last but not least, continuous training in quality related matters. Continuing education programs, on the other hand, should cover quality training and should emphasize life-cycle cost analysis to make sure that funds for the operation and maintenance of the completed facility are considered properly during the initial feasibility study and are earmarked for use in the operation phase. 
APPENDIX I. QUESTIONNAIRE

\section{ILLINOIS INSTITUTE OF TECHNOLOGY \\ DEPARTMENT OF CIVIL ENGINEERING \\ CHICAGO}

RESEARCH UNIT 8

QUALITY IN THE CONSTRUCTION PROCESS

QUESTIONNAIRE

Please answer these questions:

1. Name:

2. What is your major?

3. Do you have any design experience?

months

4. Do you have any site experience?

months

5. Was "quality" treated in any course/seminar you took so far?

Yes $\square \quad$ No

Please rate the importance you attach to each of these items on a scale of $1-5$, by circling the appropriate number to the right of each item.

\section{Factors that Affect Quality in the Design Phase}

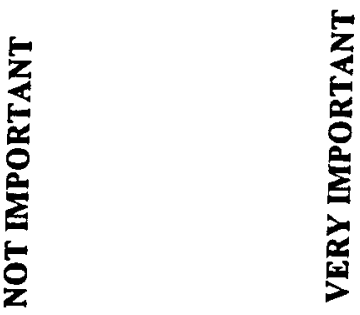

1. Level of cooperation of design professionals $\quad 1 \quad$\begin{tabular}{llll}
2 & 3 & 4 & 5 \\
\hline
\end{tabular} (Within the same design firm)

2. Extent of teamwork of parties participating in the design phase (Structural, mechanical, electrical, environmental, civil engineers, architects, owners)

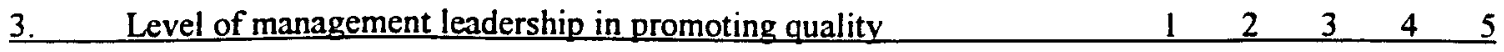

4. Level of management commitment to continuous quality improvement $1 \quad \begin{array}{lllll}2 & 3 & 4 & 5\end{array}$ 
5. Use of statistical methods

\begin{tabular}{lllll}
1 & 2 & 3 & 4 & 5 \\
\hline
\end{tabular}

(Control charts, histograms, check sheets, graphs, etc. used to get

information about errors, variations, reworks, etc.)

6. Existence of feedback system

\begin{tabular}{lllll}
1 & 2 & 3 & 4 & 5 \\
\hline
\end{tabular}

(Information system used to transfer data from previous projects in

order to prevent similar errors.)

7. Constructability of the design

$\begin{array}{lllll}1 & 2 & 3 & 4 & 5\end{array}$

(Constructability reviews)

8. Educational background of designers

$\begin{array}{lllll}1 & 2 & 3 & 4 & 5\end{array}$

(Degrees received, areas of specialization, and institutions degrees

received from)

9. Extent of designers training

$\begin{array}{lllll}1 & 2 & 3 & 4 & 5\end{array}$

(In-house training courses, apprenticeship programs, continuing

education courses, seminars, etc.)

10. Selection of appropriate design firm

(Experience, skills, capabilities, workload, expertise, financial

stability, etc.)

11. Characteristics of office practices

(Physical environment, organizational structure, personnel

policy, ethical environment, etc)

12. Briefing of owner

(Establishing project objectives regarding cost, time, quality

and resources.)

13. Budget allocated for design

$\begin{array}{lllll}1 & 2 & 3 & 4 & 5\end{array}$

14. Appropriateness of project specifications

(Specifications are documents that provide technical information on

materials, performance and quality requirements)

15. Quality of codes and standards

(Federal, state and local codes, generally accepted standards)

16. Characteristics of drafting practices

(Drafting standards, use of CAD, drafting procedure, etc.)

17. Personalities of the participants

$\begin{array}{lllll}1 & 2 & 3 & 4 & 5\end{array}$

18. Other(s)

(Specify) 


\section{Factors that Affect Quality in the Construction Phase}

1. Selection of appropriate contract forms $\quad 1 \quad 2 \quad$\begin{tabular}{l}
3 \\
\hline
\end{tabular} (AIA, EJCDC, FIDIC, etc.)

2. Appropriateness of technology used in the construction process $\quad \begin{array}{llllll}1 & 2 & 3 & 4 & 5\end{array}$

3. Quality of shopdrawings received from subcontractors $\quad 1 \quad \begin{array}{lllll}2 & 3 & 4 & 5\end{array}$ (Drawings, diagrams which illustrate how specialized portions of the work are to be constructed.)

4. Adequacy of supervision/inspection by owner representative $\quad \begin{array}{lllll}2 & 3 & 4 & 5\end{array}$

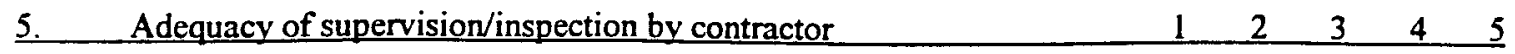

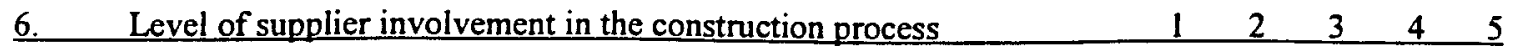

\begin{tabular}{llllll}
$7 . \quad$ Use of statistical methods & 1 & 2 & 3 & 4 & 5 \\
\hline
\end{tabular}

(Control charts, histograms, check sheets, graphs, etc. used to get

information about errors, variations, reworks, etc. in the design phase.)

8. Existence of feedback system $\quad 1 \quad \begin{array}{lllll}2 & 3 & 4 & 5\end{array}$ (Information system used to transfer data from previous projects in order to prevent similar errors.)

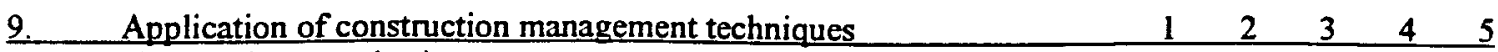
(Scheduling, monitoring progress, cost control, resource allocation, etc.)

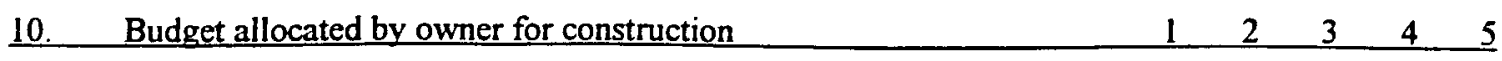

11. Personalities of the participants \begin{tabular}{llllll} 
& 1 & 2 & 3 & 4 & 5 \\
\hline
\end{tabular}

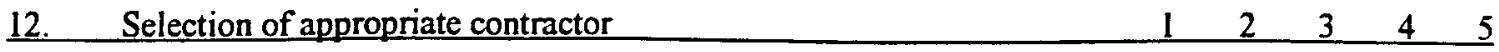

13. Extent of emplovee training bv all parties $\quad 1 \quad$\begin{tabular}{llll}
2 & 3 & 4 & 5 \\
\hline
\end{tabular}

(Contractor, subcontractors, suppliers)

14. Level of management leadership in promoting quality $\begin{array}{llllll}1 & 2 & 3 & 4 & 5\end{array}$

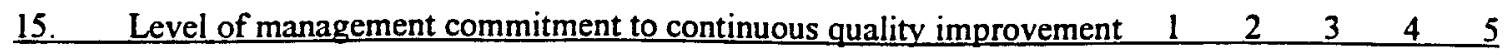

16. Level of coordination of the contractor's personnel $\quad 1 \quad \begin{array}{lllll}2 & 3 & 4 & 5\end{array}$

(Site engineers, foreman, contract managers, purchasing agent, etc.)

17. Extent of teamwork of parties participating in the construction phase $\quad 1 \quad 2 \quad 3 \quad 3 \quad 4 \quad 5 \quad 5$ (Owner, contractor, subcontractors, suppliers, designers)

18. Quality of drawings and specifications received from designer $\quad 1 \quad \begin{array}{llll}2 & 3 & 4 & 5\end{array}$

19. Other(s) \begin{tabular}{llllll}
1 & 2 & 3 & 4 & 5 \\
\hline
\end{tabular}

(Specify) 


\section{Factors that Affect Quality in the Operations and Maintenance Phase}

\begin{tabular}{|c|c|c|c|c|c|c|}
\hline & Extent of training of operations and maintenance personnel & 1 & 2 & 3 & 4 & 5 \\
\hline ( & Existence of an operation and maintenance manual & 1 & 2 & 3 & 4 & $\underline{5}$ \\
\hline$\underline{3}$ & Ability to operate the facility within design limits & 1 & 2 & 3 & 4 & $\underline{5}$ \\
\hline 4 & Level of management leadership in promoting quality & 1 & 2 & 3 & 4 & 5 \\
\hline$\underline{5}$ & Level of management commitment to continuous quality improvement & 1 & 2 & 3 & 4 & $\underline{5}$ \\
\hline 6 & Personalities of the participants & 1 & 2 & 3 & 4. & $\underline{5}$ \\
\hline 7. & Use of computers in operation and maintenance & 1 & 2 & 3 & 4 & $\underline{5}$ \\
\hline$\underline{8}$. & Budget allocated by owner for operations and maintenance & 1 & $\underline{2}$ & 3 & 4 & $\underline{5}$ \\
\hline 9 & Other(s) & & 2 & 3 & 4 & 5 \\
\hline
\end{tabular}

\section{APPENDIX II. REFERENCES}

Arditi, D. (1984). "Graduate education in construction management." Constr. Mgmt. and Economics, 2(3), 193-199.

Arditi, D., and Gunaydin, H. M. (1997). "Total quality management in the construction process.' Int. J. Proj. Mgmt., 15(4), 235-243.

Arditi, D., and Gunaydin, H. M. (1998). "Factors that affect process quality in the life-cycle of building projects.' J. Constr. Engrg. and Mgmt., ASCE, 124(3), 194-203.

Covey, S. R. (1990). The seven habits of highly effective people: Restoring the character ethic. Simon and Schuster, New York.

Crosby, P. B. (1967). Cutting the cost of quality. Farnsworth Publishing Company, Boston.

Crosby, P. B. (1992). Completeness: Quality for the 21st century. Penguin, New York.

Delbecq, A. L., and Gustafson, D. H. (1975). Group techniques for program planning: A guide to nominal group and delphi process. Scott, Foresman Publishers, Glenview, Ill.

Deming, W. E. (1986). Out of the crisis. MIT Center for Advanced Educational Services, Cambridge, Mass.

Drucker, P. F. (1993). Managing for the future. Truman Talley Books/ Plume, New York.

Ferguson, H., and Clayton, L., eds. (1988). Quality in the constructed project: A guideline for owners, designers and constructors. Vol. 1, ASCE, New York.

Hammer, M. (1996). Beyond reengineering. HarperCollins, New York. Iami, M. (1986). Kaizen, the key to Japan's competetive success. McGraw-Hill, New York.
Juran, J. M., ed. (1988). Juran's quality control handbook, 4th Ed., McGraw-Hill, New York.

Juran, J. M. (1993). Quality planning and analysis: From product development through use. McGraw-Hill, New York.

Ledbetter, B. S. (1985). "Pioneering construction management education." J. Constr. Engrg. and Mgmt., ASCE, 111(1), 41-51.

Milton, J. S., and Arnold, J. C. (1990). Probability and statistics in the engineering and computer sciences. McGraw-Hill, New York.

Nagasaku, C., and Oda, M. (1965). Planning and execution of quality control. Juse Press, Tokyo.

Neave, H. R. (1990). The Deming dimension. SPC Press, Knoxville, Tenn.

O’Brien, J. J. (1989). Construction inspection handbook, 3rd Ed., Van Nostrand Reinhold, New York.

Russell, J. S. (1991). "The challenge: Recruiting students to civil engineering." J. Profl. Issues in Engrg. Educ. and Pract., ASCE, 117(1), $21-26$.

Stasiowski, F. A., and Burstein, D. (1994). Total quality project management for the design firm. Wiley, New York.

"The top 100 construction management firms." (1994a). ENR, 232(24), $38-48$.

"The top 150 property management firms." (1994b). Com. Prob. News, 4(2), 8-16.

"The top 400 contractors." (1994c). ENR, 232(5), 45-60.

"The top 500 design firms." (1994d). ENR, 232(14), 34-78.

Yates, J. K. (1994). "Construction education: Computerized evaluation system." Trans., AACE, 3.1-3.8. 